\title{
In vitro evaluation of the cytotoxic activity of three epoxy resin-based endodontic sealers
}

\author{
Giuseppe TROIANO*, Donatella PERRONE*, Mario DIOGUARDI, Alessio BUONAVOGLIA, Fatima ARDITO \\ and Lorenzo LO MUZIO
}

Department of Clinical and Experimental Medicine, University of Foggia, Foggia 71122, Italy
Corresponding author, Donatella PERRONE; E-mail: donatella.perrone@unifg.it

\begin{abstract}
The aim of the study was to evaluate the cytotoxicity of three epoxy resin-based endodontic sealer, AH Plus, Sicura Seal and Top Seal. Direct and indirect cytotoxicity were evaluated by 3-(4,5-dimethylthiazol-2-yl)-2,5-diphenyl tetrazolium bromide assay and LIVE/DEAD ${ }^{\circledR}$ Viability/Cytotoxicity Assay on MG63 osteoblasts-like cells. Data were statistically analyzed by analysis of variance and Tukey test, setting a significance level of $5 \%$. Both results related to direct and indirect cell viability tests showed that all groups were significantly more cytotoxic than the negative control group. The cytotoxicity activity after one week of culture showed the absence of direct cytotoxicity, while a medium rate of indirect cytotoxicity. All the three epoxy resin-based sealers (AH Plus, Top Seal and Sicura Seal) showed a medium rate of cytotoxicity on osteoblasts-like cells in vitro. No significant difference was found among the sealers analyzed.
\end{abstract}

Keywords: Endodontic, Resin sealer, Epoxy resin, Cytotoxicity, Biocompatibility

\section{INTRODUCTION}

A complete sealing of the root canal system after cleaning and shaping is critical for a successful endodontic treatment ${ }^{1}$. The final purpose of the sealing is to create a barrier with the aim of protecting the peri-radicular tissues by penetration of microorganisms that reside in the oral cavity ${ }^{2}$. Although new strategies have been developed for the filling and sealing of the root canal ${ }^{3,4)}$, the traditional technique involving the use of guttapercha combined with a root canal sealer still represents one of the most common approaches used by clinicians ${ }^{5}$. A root canal sealer fills the gaps present between guttapercha points and the walls of the root canal in order to prevent any possible penetration of microorganisms ${ }^{6}$. Different classes of endodontic sealers with considerably different formulations have been developed until today. These classes comprise: zinc oxide-eugenol-7), calcium hydroxide-based ${ }^{8}$, calcium silicate-based ${ }^{9}$, glass ionomer-based ${ }^{10)}$, silicon-based ${ }^{11)}$ and epoxy resinbased $^{12)}$ endodontic sealers. Epoxy-resin sealers are among the products most commonly used in the clinical practice. They exhibit very low shrinkage rates during setting, as well as long-term dimensional stability, and polymerization with null or minimum release of formaldehyde ${ }^{13)}$. They are also able to bond to dentin and exert a good sealing ability, in addition they present antimicrobial feature ${ }^{14}$. As shown in previous studies, the epoxy-based sealers currently used in endodontics exhibit a variable degree of cytotoxicity ${ }^{15}$.

In fact, although endodontic sealers are designed to be used only within the root canal during endodontic

\footnotetext{
*Authors who contributed equally to this work.
}

Color figures can be viewed in the online issue, which is available at J-STAGE.

Received May 9, 2017: Accepted Aug 10, 2017

doi:10.4012/dmj.2017-148 JOI JST.JSTAGE/dmj/2017-148 therapy, sometimes they can extrude through the apical constriction $^{16)}$. Even without extrusion, eluents derived from these materials may come into direct contact with the peri-radicular tissues over extended periods of times, causing irritation that result in delayed wound healing ${ }^{17)}$. Thus, the biocompatibility of the root canal sealer, especially regarding both the tissues and cell types present into the area of concern, is an important factor when clinicians choose the best material ${ }^{18)}$.

The aim of this study was to evaluate and compare, in vitro, the cytotoxicity of three different (AH-Plus, Top Seal and Sicura Seal) epoxy resin-based endodontic sealers.

\section{MATERIALS AND METHODS}

\section{Preparation of specimens and eluates}

Three root canal sealers: AH Plus (Dentsply/Maillefer, Konstanz, Germany), Sicura Seal (Dentalica, Milano, Italy) and Top Seal (Dentsply De Trey, Konstanz, Germany) evaluated in this study were obtained from their respective manufacturers and prepared as described by manufacturers' instructions. Composition of the root canal sealers is reported on Table 1. Each sample disc was shaped with 2 -mm-thick nonreactive Teflon molds with a diameter of $6-\mathrm{mm}$ under aseptic conditions and then was allowed to set for $24 \mathrm{~h}$ at $37^{\circ} \mathrm{C}$ in $100 \%$ humidity. Samples were placed in 24 -wells tissue culture plates, washed twice with phosphate-buffered solution (PBS), dried under laminar flow for $24 \mathrm{~h}$ at room temperature and sterilized with an exposition to ultraviolet light for $20 \mathrm{~min}$ on each surface, before being added to cell cultures.

Discs were placed at the bottom of 24-wells tissue 
Table 1 Components and manufacturers of the three sealers tested

\begin{tabular}{lll}
\hline \multicolumn{1}{c}{ Materials } & \multicolumn{1}{c}{ Component A } & \multicolumn{1}{c}{ Component B } \\
\hline $\begin{array}{l}\text { AH Plus } \\
\text { (Dentsply/Maillefer, } \\
\text { Konstanz, Germany) }\end{array}$ & $\begin{array}{l}\text { Bisphenol-A and -F epoxy resin, } \\
\text { calcium tungstate, zirconium oxide, } \\
\text { silica, iron oxide pigments }\end{array}$ & $\begin{array}{l}\text { Adamantane amine, } \\
\text { N,N-dibenzyl-5-oxanonane, TCD-diamine, } \\
\text { calcium tungstate, zirconium oxide, silicon oil }\end{array}$ \\
$\begin{array}{l}\text { Top Seal } \\
\text { (Dentsply De Trey, } \\
\text { Konstanz, Germany) }\end{array}$ & $\begin{array}{l}\text { Bisphenol-A and -F epoxy resin, } \\
\text { calcium tungstate, zirconium oxide, } \\
\text { silica, iron oxide pigments }\end{array}$ & $\begin{array}{l}\text { Dibenzyldiamine, aminoadamantane, } \\
\text { TCD-diamine, calcium tungstate, } \\
\text { zirconium oxide }\end{array}$ \\
$\begin{array}{l}\text { Sicura Seal } \\
\text { (Dentalica, Milano, Italy) }\end{array}$ & $\begin{array}{l}\text { Epoxyoligomerresin, } \\
\text { ethyleneglycolsalicylate, calcium phosphate, } \\
\text { bismuth carbonate, zirconium oxide }\end{array}$ & $\begin{array}{l}\text { Poly aminobenzoate, triethanolamine, } \\
\text { calcium phosphate, bismuth carbonate, } \\
\text { zirconium oxide, calcium oxide }\end{array}$ \\
\hline
\end{tabular}

culture plates containing culture medium (Dulbecco's minimal essential medium, DMEM, Sigma Aldrich, Saint Louis, MO, USA) and incubated $\left(37^{\circ} \mathrm{C}\right.$ and $95 \%$ relative humidity) for $1,2,3$ and 7 days. According to ISO standards 10993-5, the surface area to volume ratio used for eluates preparation was approximately 250 $\mathrm{mm}^{2} / \mathrm{mL}^{19)}$. The eluates were collected after different incubation times and passed through $0.22 \mu \mathrm{m}$ filters for the subsequent evaluation. DMEM without materials was incubated for each time point and was uses as control.

\section{Cell culture and treatment}

MG63 osteoblast-like cells were cultivated in DMEM supplemented with $10 \% \mathrm{FBS}$ and penicillin (100 U/mL) and streptomycin $(100 \mu \mathrm{g} / \mathrm{mL})$ at $37^{\circ} \mathrm{C}$ in a humidified incubator under ambient pressure air atmosphere containing $5 \% \mathrm{CO}_{2}$. Trypsin was used to passage cultures whenever they were grown to confluence.

\section{Direct cytotoxicity testing}

The direct cytotoxicity of materials was evaluated as percentage cell viability, using the 3-(4,5-dimethylthiazolyl-2-yl)-2,5-diphenyltetrazolium bromide (MTT) assay. The MG63 cells at $2 \times 10^{4}$ cells per well were seeded into a 96 -wells plate with $150 \mu \mathrm{L}$ medium. After direct exposure to the materials discs for 1, 2, 3 and 7 days, cell viability was detected. the supernatant was removed and replaced with $0.5 \mathrm{mg} / \mathrm{mL}$ MTT solution (Sigma Aldrich) in DMEM was added to each well, and then the wells were incubated for $4 \mathrm{~h}$ under standard culturing conditions. After incubation time, the medium was gently removed from each well and crystallized formazan dye was solubilized with $100 \mu \mathrm{L}$ Dimethyl sulfoxide (DMSO, Sigma Aldrich). The plates were then shaken until the crystals had dissolved. Reduced MTT was then measured spectrophotometrically at $540 \mathrm{~nm}$ in a microplate UVVis spectrophotometer (Multiskan go, Thermo Scientific, Waltham, MA, USA). As negative control, the cells were exposed to the medium only. The experiments were performed in triplicate per condition and were repeated in 3 independent experiments. Cell viability data were calculated as the percentage of the control group and were expressed as the mean \pm s.e.m (standard error of mean). Cytotoxicity was rated as 1) high cytotoxicity for $<30 \%$ cell viability, 2) mid cytotoxicity for $30-59 \%$ cell viability, low cytotoxicity for $60-90 \%$ cell viability and not cytotoxic for $>90 \%$ cell viability.

\section{Indirect cytotoxicity testing}

The indirect cytotoxicity of materials was examined using MTT assay. The MG63 cells at $2 \times 10^{4}$ cells per well are seeded into a 96-wells plate with $150 \mu \mathrm{L}$ DMEM medium. After overnight attachment, medium was removed and replaced by $150 \mu \mathrm{L}$ sealer eluate, prepared as previously described. After $24 \mathrm{~h}$, the MTT assay was performed as described above. Reduced MTT was then measured spectrophotometrically at $540 \mathrm{~nm}$ in a microtiter plate reads (Multiskan go, Thermo Fisher Scientific). As negative control the cells were exposed to DMEM medium. The experiments were performed in 3 wells per condition and were repeated in 3 independent experiments.

\section{Fluorescence-based evaluation of cell viability}

Test was performed after washing every trans well with PBS, and carried out using the LIVE/DEAD ${ }^{\circledR}$ Viability/ Cytotoxicity Assay kit for mammalian cells (Invitrogen, Waltham, MA, USA). After incubation time of $3 \mathrm{~h}$, the images were acquired using a fluorescence microscopy (EVOS FL, Thermo Fisher Scientific), and automatically counted using ImageJ software (National Institutes of Health, Maryland, MD, USA).

\section{Data and statistical analysis}

Assessment of the presence of a normal distribution was performed with Kolgomorov-Smirnoff test. After that, data were statistically analyzed by one-way analysis of variance (ANOVA), and comparison among groups was performed using Tukey multiple comparison test. The statistical significance level was established at $p$-value $<0.05$.

\section{RESULTS}

Both results related to direct and indirect cell viability tests showed that all groups were significantly more 
cytotoxic than the negative control group $(p<0.05)$. The direct cytotoxicity, in all three groups, tended to decrease during the time, and after 7 days all the sealers were not cytotoxic compared to controls. In addition, Sicura Seal showed the best pattern of biocompatibility at the 2 day, while AH PLUS resulted more cytotoxic until the third day. Details of the differences found among the different epoxy-based sealers is shown in Table 2 .

Results related to the indirect cytotoxicity test revealed that, elutes derived from all the sealers were significantly more cytotoxic than the negative controls up to 7 days from the starting time $(p<0.05)$. No differences were found among the three tested sealers at days 1 and 7. However, at days 2 and 3 Sicura Seal resulted

Table 2 Optical density of the samples (mean \pm s.e.m) at 1, 2, 3 and 7 days after evaluation of direct (A) or indirect (B) cytotoxicity

\begin{tabular}{|c|c|c|c|c|c|}
\hline \multicolumn{2}{|c|}{ time [day] } & AH Plus & Top Seal & Sicura Seal & Control \\
\hline \multirow{4}{*}{$\mathrm{A}$} & 1 & $0.478^{\mathrm{a}, \mathrm{A}} \pm 0.080$ & $0.544^{\mathrm{b}, \mathrm{C}_{ \pm}} \pm .030$ & $0.543^{\mathrm{c}, \mathrm{E}} \pm 0.019$ & $0.742^{\mathrm{a}, \mathrm{b}, \mathrm{c}} \pm 0.038$ \\
\hline & 2 & $0.632^{\mathrm{d}, \mathrm{f}, \mathrm{A}, \mathrm{B}} \pm 0.021$ & $0.712^{\mathrm{e}, \mathrm{C}, \mathrm{D}} \pm 0.036$ & $0.770^{\mathrm{f}, \mathrm{E}} \pm 0.067$ & $0.858^{\mathrm{d}, \mathrm{e}} \pm 0.010$ \\
\hline & 3 & $0.707^{\mathrm{g}, \mathrm{h}, \mathrm{i}, \mathrm{A}} \pm 0.040$ & $0.861^{\mathrm{g}, \mathrm{C}, \mathrm{D}} \pm 0.028$ & $0.856^{\mathrm{h}, \mathrm{E}} \pm 0.032$ & $0.931^{i} \pm 0.023$ \\
\hline & 7 & $0.820^{\mathrm{A}, \mathrm{B}} \pm 0.035$ & $0.834^{\mathrm{C}, \mathrm{D}} \pm 0.021$ & $0.848^{\mathrm{E}} \pm 0.013$ & $0.935 \pm 0.028$ \\
\hline \multirow{4}{*}{$\mathrm{B}$} & 1 & $0.488^{1, \mathrm{~F}} \pm 0.030$ & $0.430^{\mathrm{p}} \pm 0.011$ & $0.431^{t} \pm 0.056$ & $0.636^{1, p, t} \pm 0.003$ \\
\hline & 2 & $0.508^{\mathrm{m}} \pm 0.090$ & $0.510^{\mathrm{q}} \pm 0.010$ & $0.403^{u} \pm 0.009$ & $0.587^{\mathrm{m}, \mathrm{q}, \mathrm{u}} \pm 0.080$ \\
\hline & 3 & $0.567^{\mathrm{n}} \pm 0.016$ & $0.636^{r, \mathrm{G}_{ \pm}}+0.027$ & $0.415^{\mathrm{v}, \mathrm{H}_{ \pm}} \pm .042$ & $0.738^{\mathrm{n}, \mathrm{r}, \mathrm{v}} \pm 0.014$ \\
\hline & 7 & $0.610^{\circ, \mathrm{F}} \pm 0.010$ & $0.703^{\mathrm{s}, \mathrm{G}_{ \pm}} \pm 0.008$ & $0.578^{\mathrm{z}, \mathrm{H}_{ \pm}} 0.030$ & $0.842^{\mathrm{o}, \mathrm{s}, \mathrm{z}} \pm 0.010$ \\
\hline
\end{tabular}

Different uppercase in each column indicate statistical difference in period, while different lowercase letters in each row indicate difference between materials.

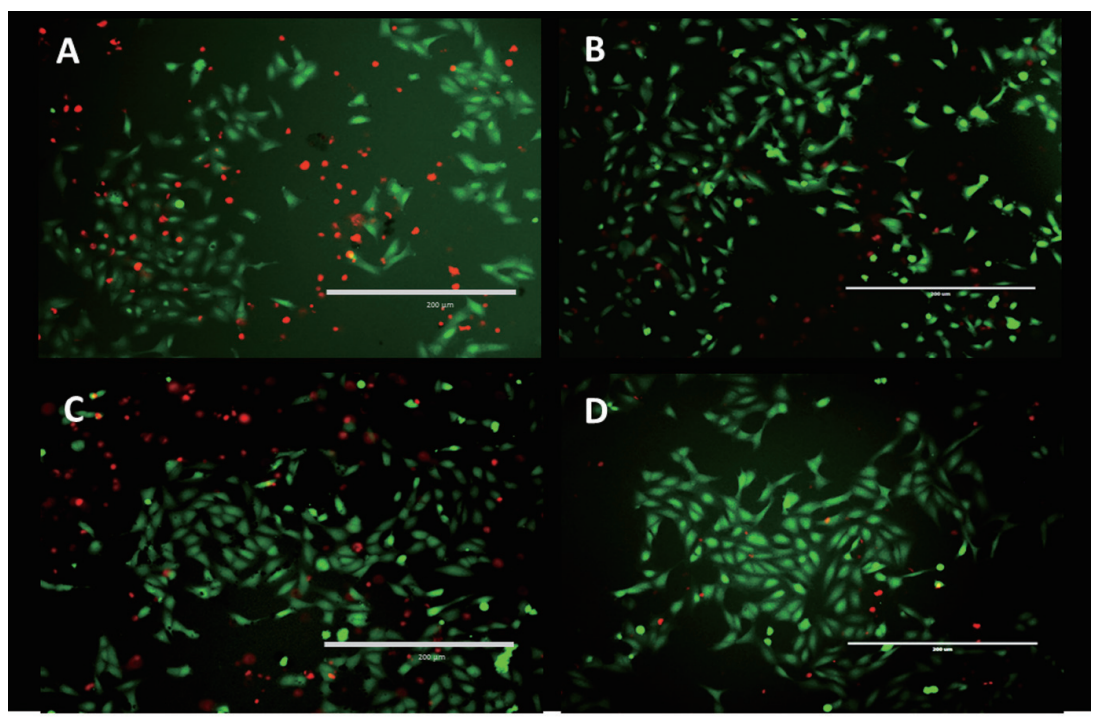

E

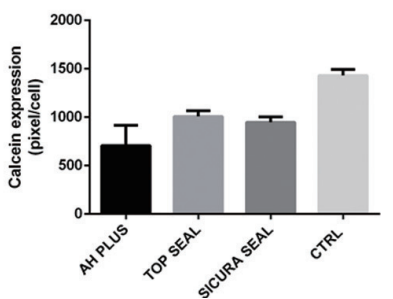

$\mathbf{F}$

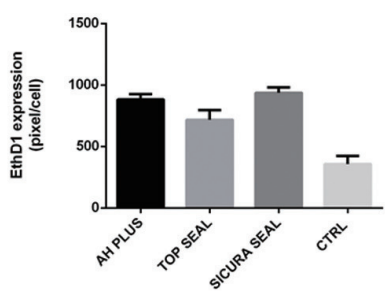

Fig. 1 Fluorescence vitality images of MG63 cells after $3 \mathrm{~h}$ of cultured in direct contact with endodontic materials discs: (A) AH Plus, (B) Top Seal, (C) Sicura Seal, (D) negative control (only MG63).

Quantitative pixel expression of calcein (E) and Etdh1 (F). No significant statistical differences were detected 
to be more cytotoxic $(p<0.05)$ than both Top Seal and AH PLUS, while no significant differences have been detected between the aforementioned sealers.

The fluorescence assay representative of each materials in contact with MG63 cells is shown in Fig. 1. As clearly shown, in the negative control (D) an intense uniform green fluorescence in live cells is visible (ex/em $\sim 495 \mathrm{~nm} / \sim 515 \mathrm{~nm}$ ), this is due to the polyanionic dye calcein that is well retained within live cells. In the other hand, The cell-impermeant viability indicator ethdium homodimer-1 (EthD-1) is a high-affinity nucleic acid stain that is weakly fluorescent until bound to DNA, thereby producing a bright red fluorescence in dead cells (ex/em maxima 528/617). The fluorescence images obtained after $3 \mathrm{~h}$ of incubation with tested materials confirmed the cytotoxicity results: A higher number of dead cells was visible in cultures exposed to AH Plus (A), Top Seal (B) and Sicura Seal (C), compared to the negative control (D). A lower number of dead cells was observed in cultures exposed to Top Seal (B).

\section{DISCUSSION}

Biocompatibility of root canal sealers represents one of the most important features for a safe and successful use of these cements in the clinical practice ${ }^{20)}$. In fact, sealers are usually confined within the root, but an accidental extrusion towards the periradicular space is a common finding after the execution of a final X-ray ${ }^{21,222}$. A direct contact may occur in a microleakage and disruption of the endodontic sealer ${ }^{23}$, the possibility that exudates, containing products of polymerization and/or degradation, pass through the root canal and reach the neighboring tissues ${ }^{24}$. Therefore, a cytotoxic sealer could hinder the process of tissue repair.

Various parameters can influence the rate of biocompatibility of a sealer, among these: type of leachable components, setting time, stability of adhesion and polymerization, and the contact area between the sealer and the adjacent soft and hard tissue ${ }^{15,18)}$. For the aforementioned reasons, both in vitro and in vivo test must be performed before their clinical use.

The aim of this study was to evaluate the cytotoxic activity of three epoxy resin-based root canal sealers and compare among them in the same in vitro conditions. Cytotoxicity was evaluated both with MTT assay and LIVE/DEAD fluorescence assay. The former has been extensively used in the previous studies and was applied both for the evaluation of direct and indirect cytotoxicity ${ }^{11,25)}$, while the fluorescence assay was performed only for the evaluation of the direct cytotoxicity ${ }^{26}$. MG63 osteoblast-like cells were used for all the test performed, such cells are characterized by an high rate of proliferation ${ }^{27,28)}$.

The analysis of direct cytotoxicity simulated the clinical situation in which a direct contact happens between the freshly mixed sealer and the surrounding tissues. Results of this study revealed that all the three based sealers were moderately cytotoxic in the short term, while it tends to decrease with time. The short term cytotoxic activity has been also revealed by the fluorescence assay, with Top Seal leading to the lowest number of cell death, although no statistical difference was registered (Fig. 1). The analysis of indirect cytotoxic, performed on eluates extracted from sealers after 1 day of curing, revealed that all the sealers showed a moderate rate of cytotoxicity that tend to not decrease after a week of cell culture.

Results from this study are in agreement with what has already been reported in the literature ${ }^{23,28-30)}$. It's to emphasize that most of the data present in the literature, are related to the use of AH Plus and Top Seal, while, to our knowledge, no previous studies have evaluated the cytotoxicity of Sicura Seal. The cytotoxicity of this class of sealers seems to be related to its epoxy resin compound and to the type of polymerization promoted by the amines ${ }^{31)}$. In fact, the polymerization of such materials is characterized by anionic ring-opening reaction in the presence of primary amine ${ }^{32}$. However, the waste products of such reaction have been supposed be toxic for cells ${ }^{33)}$. It has also been supposed that the cytotoxicity of epoxy resin-based sealer was due to the release of bisphenol A diglycidyl, which is known to be a mutagenic component of resin-based materials $\mathrm{s}^{34}$. However, such compound is not present in the chemical composition of Sicura Seal, despite exudates from such sealer resulted the to be the more cytotoxic among that analyzed. In addition to such mechanism, epoxy resin-based sealers could release a minute amounts of formaldehyde that may explain their toxicity in the short-term ${ }^{35}$. It's to note, however, that the conditions reported in this study are a very stressful simulation to what happens clinically. In fact, fluids present in the human body work to decrease the contact between the extruded sealers and exudates on the periradicular tissues. In addition, the amount of sealer that directly comes in contact with the aforementioned tissues varies from case to case, and therefore a precise standardization in vitro is unlikely to be able to accurately simulate a common clinical situation. For such reasons, further in vivo researches are needed for a more comprehensive understanding of the mechanisms and quantify possible damages which could be induced by the use of such materials.

\section{CONCLUSIONS}

Analysis of the cytotoxicity of AH Plus, Top Seal and Sicura Seal revealed that all the three epoxy resinbased sealers possess a moderate grade of cytotoxicity on human osteoblast-like cells. A direct cytotoxicity is present in the short term when sealers come directly in contact with cells, but it tends to strongly decrease after a week. While, cytotoxicity due to the release of exudates is present also after a week of culture. No differences have been found regarding the comparison of the three endodontic root canal sealers analyzed. 


\section{CONFLICTS OF INTEREST}

The authors deny any conflicts of interest related to this study.

\section{REFERENCES}

1) Schilder H. Filling root canals in three dimensions. Dent Clin North Am 1967: 723-744.

2) Ray HA, Trope M. Periapical status of endodontically treated teeth in relation to the technical quality of the root filling and the coronal restoration. Int Endod J 1995; 28: 12-18.

3) Jho W, Park JW, Kim E, Song M, Seo DG, Yang DK, Shin SJ. Comparison of root canal filling quality by mineral trioxide aggregate and gutta percha cones/AH plus sealer. Dent Mater J 2016; 35: 644-650.

4) Castelo-Baz P, Martin-Biedma B, Lopes MM, Pires-Lopes L, Silveira J, Lopez-Rosales E, Varela-Patino P. Ultramicroscopic study of the interface and sealing ability of four root canal obturation methods: Resilon versus gutta-percha. Aust Endod J 2013; 39: 159-163.

5) Tomson RM, Polycarpou N, Tomson PL. Contemporary obturation of the root canal system. Br Dent J 2014; 216: 315322 .

6) Grossman LI. An improved root canal cement. J Am Dent Assoc 1958; 56: 381-385.

7) Barros J, Costa-Rodrigues J, Lopes MA, Pina-Vaz I, Fernandes MH. Response of human osteoblastic and osteoclastic cells to $\mathrm{AH}$ plus and pulp canal sealer containing quaternary ammonium polyethylenimine nanoparticles. J Endod 2014; 40: 1149-1155.

8) Mohammadi Z, Karim Soltani M, Shalavi S, Yazdizadeh M, Jafarzadeh M. Calcium hydroxide-based root canal sealers: an updated literature review. Compend Contin Educ Dent 2014; 35: 334-339; quiz 40.

9) Collado-Gonzalez M, Garcia-Bernal D, Onate-Sanchez RE, Ortolani-Seltenerich PS, Lozano A, Forner L, Llena C, Rodriguez-Lozano FJ. Biocompatibility of three new calcium silicate-based endodontic sealers on human periodontal ligament stem cells. Int Endod J 2017; 50: 875-884.

10) Tanomaru-Filho M, Jorge EG, Tanomaru JM, Goncalves M. Evaluation of the radiopacity of calcium hydroxide- and glass-ionomer-based root canal sealers. Int Endod J 2008; 41: 50-53.

11) Silva EJ, Neves AA, De-Deus G, Accorsi-Mendonca T, Moraes AP, Valentim RM, Moreira EJ. Cytotoxicity and gelatinolytic activity of a new silicon-based endodontic sealer. J Appl Biomater Funct Mater 2015; 13: e376-380.

12) Cakici F, Cakici EB, Ceyhanli KT, Celik E, Kucukekenci FF, Gunseren AO. Evaluation of bond strength of various epoxy resin based sealers in oval shaped root canals. BMC Oral Health 2016; 16: 106.

13) Carvalho-Junior JR, Correr-Sobrinho L, Correr AB, Sinhoreti MA, Consani S, Sousa-Neto MD. Solubility and dimensional change after setting of root canal sealers: a proposal for smaller dimensions of test samples. J Endod 2007; 33: 11101116.

14) McMichen FR, Pearson G, Rahbaran S, Gulabivala K. A comparative study of selected physical properties of five rootcanal sealers. Int Endod J 2003; 36: 629-635.

15) Karapinar-Kazandag M, Bayrak OF, Yalvac ME, Ersev H, Tanalp J, Sahin F, Bayirli G. Cytotoxicity of 5 endodontic sealers on L929 cell line and human dental pulp cells. Int Endod J 2011; 44: 626-634.

16) Bernath M, Szabo J. Tissue reaction initiated by different sealers. Int Endod J 2003; 36: 256-261.

17) Ricucci D. Apical limit of root canal instrumentation and obturation, part 1. Literature review. Int Endod J 1998; 31: 384-393.

18) Geurtsen W. Biocompatibility of root canal filling materials. Aust Endod J 2001; 27: 12-21.

19) ISO. Biological evaluation of medical devices. Part 5: Tests for in vitro cytotoxicity. ISO 10993-5: 2009.

20) Murphy WM. The testing of endodontic materials in vitro. Int Endod J 1988; 21: 170-177.

21) Gambarini G, Plotino G, Grande NM, Testarelli L, Prencipe M, Messineo D, Fratini L, D’Ambrosio F. Differential diagnosis of endodontic-related inferior alveolar nerve paraesthesia with cone beam computed tomography: a case report. Int Endod J 2011; 44: 176-181.

22) Jorge EG, Tanomaru-Filho M, Guerreiro-Tanomaru JM, Reis JM, Spin-Neto R, Goncalves M. Periapical repair following endodontic surgery: two- and three-dimensional imaging evaluation methods. Braz Dent J 2015; 26: 69-74.

23) Bouillaguet S, Wataha JC, Lockwood PE, Galgano C, Golay A, Krejci I. Cytotoxicity and sealing properties of four classes of endodontic sealers evaluated by succinic dehydrogenase activity and confocal laser scanning microscopy. Eur J Oral Sci 2004; 112: 182-187.

24) Barbosa SV, Araki K, Spangberg LS. Cytotoxicity of some modified root canal sealers and their leachable components. Oral Surg Oral Med Oral Pathol 1993; 75: 357-361.

25) Bin CV, Valera MC, Camargo SE, Rabelo SB, Silva GO, Balducci I, Camargo CH. Cytotoxicity and genotoxicity of root canal sealers based on mineral trioxide aggregate. J Endod 2012; 38: 495-500.

26) Bulit F, Grad I, Manoil D, Simon S, Wataha JC, Filieri A, Feki A, Schrenzel J, Lange N, Bouillaguet S. Antimicrobial activity and cytotoxicity of 3 photosensitizers activated with blue light. J Endod 2014; 40: 427-431.

27) Dioguardi M, Perrone D, Troiano G, Laino L, Ardito F, Lauritano F, Cicciu M, Lo Muzio L. Cytotoxicity evaluation of five different dual-cured resin cements used for fiber posts cementation. Int J Clin Exp Med 2015; 8: 9327-9333.

28) Xu P, Liang J, Dong G, Zheng L, Ye L. Cytotoxicity of RealSeal on human osteoblast-like MG63 cells. J Endod 2010; 36: 4044.

29) Tai KW, Huang FM, Chang YC. Cytotoxic evaluation of root canal filling materials on primary human oral fibroblast cultures and a permanent hamster cell line. J Endod 2001; 27: 571-573.

30) Sousa CJ, Montes CR, Pascon EA, Loyola AM, Versiani MA. Comparison of the intraosseous biocompatibility of AH Plus, EndoREZ, and Epiphany root canal sealers. J Endod 2006; 32: 656-662.

31) Al-Hiyasat AS, Tayyar M, Darmani H. Cytotoxicity evaluation of various resin based root canal sealers. Int Endod J 2010; 43: $148-153$.

32) Kim YK, Grandini S, Ames JM, Gu LS, Kim SK, Pashley DH, Gutmann JL, Tay FR. Critical review on methacrylate resinbased root canal sealers. J Endod 2010; 36: 383-399.

33) Miletic I, Anic I, Karlovic Z, Marsan T, Pezelj-Ribaric S, Osmak M. Cytotoxic effect of four root filling materials. Endod Dent Traumatol 2000; 16: 287-290.

34) Heil J, Reifferscheid G, Waldmann P, Leyhausen G, Geurtsen W. Genotoxicity of dental materials. Mutat Res 1996; 368: 181-194.

35) Cohen BI, Pagnillo MK, Musikant BL, Deutsch AS. Formaldehyde evaluation from endodontic materials. Oral Health 1998; 88: 37-39. 